\title{
Playful waterbird: Australasian Darter (Anhinga novaehollandiae) plays with sticks
}

\author{
Ivan Sazima ${ }^{1,2}$ \\ Museu de Zoologia, Caixa Postal 6109, Universidade Estadual de Campinas, Campinas, SP, Brazil. \\ 2 Corresponding author: isazima@gmail.com
}

Received on 14 September 2018. Accepted on 27 February 2019.

\begin{abstract}
Play with objects by birds is recorded usually for nestlings and juveniles. This behaviour is regarded as important for motor development and practice of essential skills, mostly foraging and breeding. Play is recorded for the Anhinga (Anhinga anhinga) in North America. For the remaining three recognised species play with objects seems unreported. Herein I present events of play with objects by a maturing individual of the Australasian Darter (Anhinga novaehollandiae) recorded at the urban area of Sydney, southeastern Australia. In one of the play events, the darter played with a stick it broke from a partly submerged tree it was resting on. In another event, the bird picked a floating pod, tossed it into the air and caught it again. As the Australasian Darter maturing individual possibly was a male, it could be practicing to gather sticks for nest construction, whereas playing with the pod is related to prey handling.
\end{abstract}

KEY-WORDS: Anhingidae, Australia, play behaviour, play with objects, urban waterbirds.

Play with objects is recorded mostly for nestlings and juvenile birds, and is believed to improve motor development and essential skills needed later in the life cycle, such as prey handling and gathering nest material (Ficken 1977, Burghardt 1998, Kitowski 2005). This play type is recorded for several bird species in various orders, including Suliformes (Schreiber et al. 1996, Causey 2002, Mowbray 2002, Sazima 2008, Hobson 2013). Among the four recognised species of the Anhingidae (Kennedy et al. 2005, Schodde et al. 2012), play is recorded for the Anhinga (Anhinga anhinga) in North America (Frederick \& Siegel-Causey 2000, Davis-Jr. 2015, Witt 2018). For the remaining three species, I was unable to find reports about play with objects. Herein I present three events of play with objects by a maturing individual of the Australasian Darter (Anhinga novaehollandiae) recorded in Sydney, Australia.

I observed the Australasian Darter at the Parramatta River (3350'0"S; $151^{\circ} 04^{\prime} 3^{\prime \prime} \mathrm{E}, 2 \mathrm{~m}$ a.s.l.) in the urban area of Sydney, New South Wales, southeastern Australia. A condominium and a pedestrian path are in front of the observation site, which is close (about $50 \mathrm{~m}$ ) to a bridge with moderate to heavy traffic. At the opposite side of observation site, the river is bordered by mangroves and is used by cormorants and the darters as a fishing ground. I recorded the Little Pied Cormorant (Microcarbo melanoleucos), the Little Black Cormorant (Phalacrocorax sulcirostris), and the Great Cormorant (Phalacrocorax carbo) fishing, resting, and plumage drying at the same or nearby places as the darter. As records of playing events may be fortuitous and circumstantial (Sazima 2008), the three events were opportunistically observed with bare eye or through a 70-300 $\mathrm{mm}$ telephoto lens mounted on a SLR camera from a distance of about $15-20 \mathrm{~m}$. Throughout the observational sessions, I used the "ad libitum" and "sequence" samplings (Altmann 1974), which are adequate to record fortuitous or rare events. Voucher digital photographs of the best documented event are on file at the Museu de Zoologia, Universidade Estadual de Campinas (ZUEC).

On 13 March and 02 April 2018 I recorded three events of playing with objects by a maturing individual of the Australasian Darter. In two of the events (13 March, at middle afternoon), the darter left the water and perched on a partly submerged dead tree. After shaking the body to pull water excess out from its plumage, the bird carefully scanned its immediate surroundings, and opened the wings to dry the plumage. After two min, the darter looked intently at a slim branch, grabbed it with the bill and broke it (Fig. 1A). With the stick held crosswise in the bill, the darter swayed its head and neck up and down, the wings kept spread during this play (Fig. 1 B-D). After two of these swaying movements, the bird briefly ran the stick on the left wing (Fig. 2) and released the object into the water. The whole sequence lasted two min. Shortly afterwards, the darter broke a smaller stick the same way, balanced it briefly in the bill, and released the object into the water without touching 

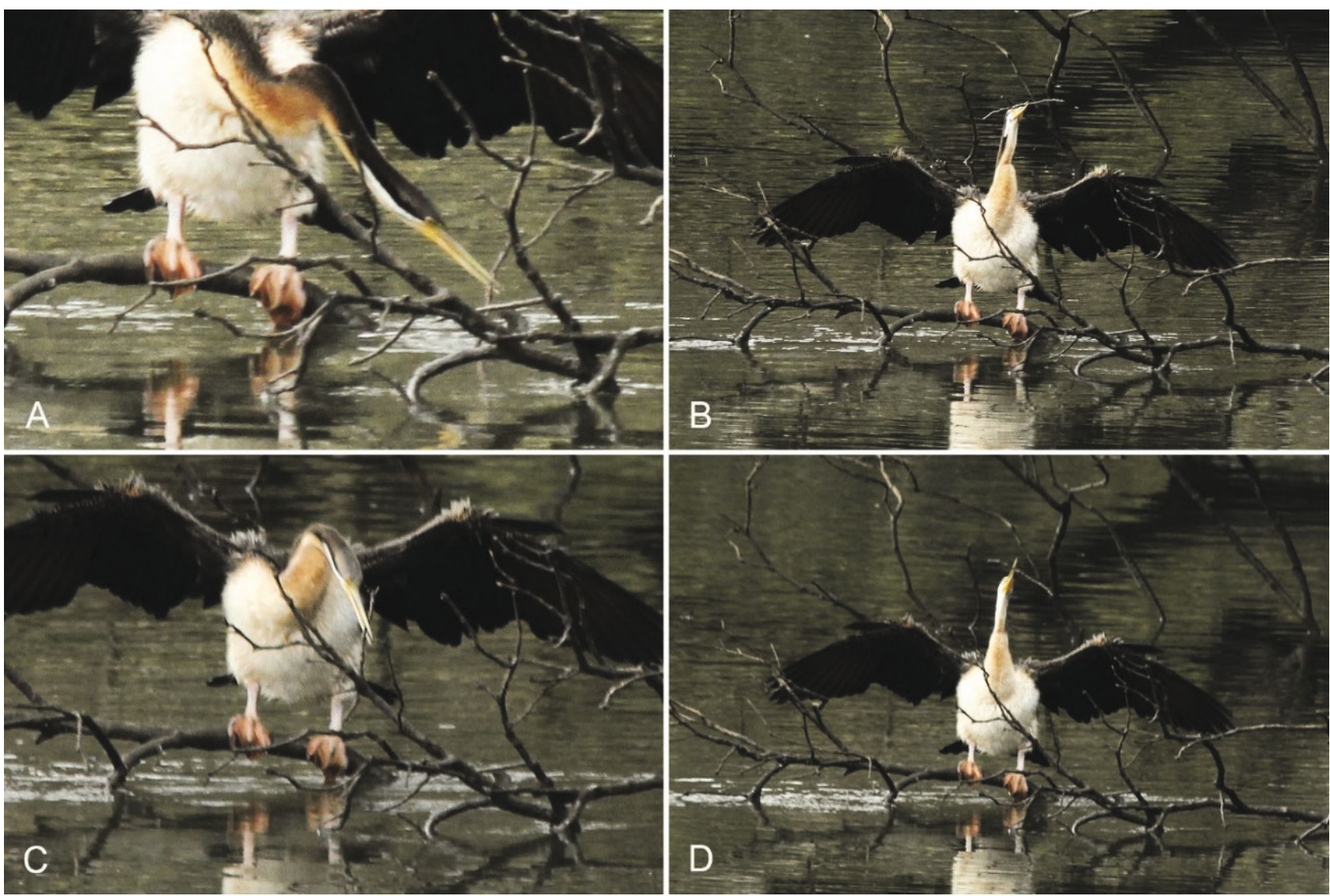

Figure 1. A maturing Australasian Darter (Anhinga novaehollandiae) individual playing with an object. After choosing a stick from its resting perch, the bird holds the object between its mandibles (A); with the stick held in the bill, the darter displays swaying movements with the head and neck $(\mathbf{B} \& \mathbf{C})$, repeated twice $(\mathbf{D})$.

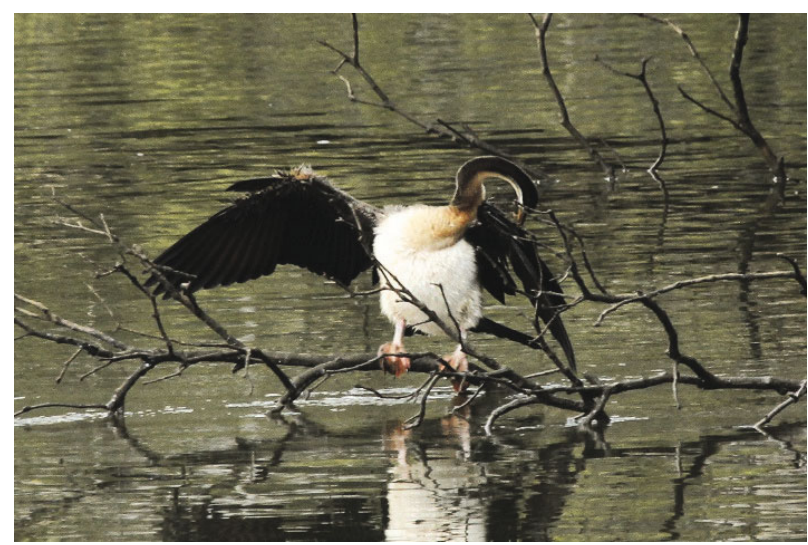

Figure 2. Subsequent to playing with the stick, the darter runs it briefly on the left wing, after which it released the object into the water.

its body as recorded in the previous event. After these two playing sequences, the bird began to preen its plumage meticulously and I left the site.

On 02 April, at late morning, I recorded the third playing event by the same Australasian Darter individual, as recognised by a natural mark on the right foot (a split webbing). The bird was perched on partly submerged dead branch and was preening the plumage, with its wings closed. A floating pod carried by the current drew the attention of the bird, which grabbed it with the bill and tossed the object into the air three times, caught it skilfully during the fall, and released it afterwards into the water. This event lasted less than a minute, after which the bird resumed preening and I left the site.

The behaviour displayed by the Australian Darter undoubtedly qualifies as play, as it meets all of the recent and strict criteria to define play in animals (Burghardt 2006): 1) limited immediate function (do not contribute to survival); 2) endogenous component (voluntary or intentional); 3) structural or temporal differences (exaggerated and awkward); 4) repeated performance (performed similarly); and 5) relaxed field (free of stress such as predator threat). This latter criterion was likely met after the careful scanning of the bird's immediate surroundings.

The present record raises the number of the apparently rare reports of Anhingidae playing with objects. It remains to be verified if this scarcity is due to lack of observational, natural history-focused studies, or if object play is actually rare, or restricted to some individuals, populations, or areas. I am inclined towards the first explanation, since Witt (2018) tells a story about young Anhingas (Anhinga anhinga) tossing sticks into the air and trying (and succeeding) to catch them again. Tossing sticks into the air and catching them is also reported for juvenile or subadult Anhingas (Davis- 
Jr. 2015). The tossing of sticks by the Anhinga and pods by the Australian Darter are likely related to practicing prey handling, as in the final phase of predation these birds toss a fish up in the air to turn it and catch it again to swallow it head first (Orta 1992, Frederick \& SiegelCausey 2000, Corbo et al. 2013, I.S., pers. obs.)

Due to the complexity of sex identification of maturing individuals of the Australasian Darter (Orta 1992, Schodde et al. 2012, Dahlem 2018, C.G. Murray pers. comm., I.S., pers. obs.), the sex of the playing bird would be an open question. However, after sightings of additional individuals near the study site from October to December 2018, my assumption is that the observed individual was a male, due to the already well-defined black line extending from the eye to the neck and partly rufous neck (see photos in Dahlem 2018). If the bird was actually a male, then it likely was practicing to gather sticks for nesting, as this part of nest construction is mostly a male role (Orta 1992, Frederick \& Siegel-Causey 2000). On the other hand, if the bird was a female, playing with sticks seems to be a slight departure from its role in nest construction later in the life-cycle, as females mostly arrange the sticks the males bring to the nest (Orta 1992, Frederick \& Siegel-Causey 2000). Whatever the sex of the playing bird, however, play with objects by the Australasian Darter is herein described and substantiated with photographs. The apparent rarity of object play in Anhingidae, including the Australian Darter, deserves a closer look and further natural history-oriented studies, especially at urban sites that would potentially constrain some behaviour types and increase alert and flight distances (Mikula 2014, Prestes et al. 2018).

\section{ACKNOWLEDGEMENTS}

I thank Marlies Sazima for loving support in the field; Ricardo Sazima and Márcia Bianchi dos Santos for lodging us in their home during our stay in Sydney; Christopher G. Murray for help with sex identification of the recorded Australasian Darter; Juliana V. Hipolito for help with the Figure 1; two anonymous reviewers for their criticism and helpful suggestions on the submitted manuscript.

\section{REFERENCES}

Altmann J. 1974. Observational study of behavior: sampling methods. Behaviour 49: 227-267.
Burghardt G.M. 1998. The evolutionary origins of play revisited: lessons from turtles, p. 1-26. In: Bekoff M. \& Byers J.A. (eds.). Animal play: evolutionary, comparative, and ecological perspectives. Cambridge: Cambridge University Press.

Burghardt G.M. 2006. The genesis of animal play: testing the limits. Cambridge: The MIT Press.

Causey D. 2002. Red-faced Cormorant (Phalacrocorax urile). In: Poole A.F. \& Gill F.B. (eds.). The birds of North America online. Ithaca: Cornell Laboratory of Ornithology. http://bna.birds.cornell.edu/ bna/species/617 (Access on 08 May 2018).

Corbo M., Macarrão A., D'Angelo G.B., Almeida C.H., Silva W.R. \& Sazima I. 2013. Aves do campus da Unicamp e arredores. Vinhedo: Avisbrasilis Editora.

Dahlem M. 2018. Australasian Darter (Anhinga novaehollandiae). https://mdahlem.net/birds/4/darter.php (Access on 10 May 2018).

Davis-Jr. W.E. 2015. Anhingas play with sticks and other plant debris. Bird Observer 43: 244-245.

Ficken M.S. 1977. Avian play. Auk 94: 573-582.

Frederick P.C. \& Siegel-Causey D. 2000. Anhinga (Anhinga anhinga). In: Poole A.F. \& Gill F.B. (eds.). The birds of North America. Ithaca: Cornell Laboratory of Ornithology. https://doi.org/10.2173/ bna.522 (Access on 08 May 2018).

Hobson K.A. 2013. Pelagic Cormorant (Phalacrocorax pelagicus). In: Poole A.F. \& Gill F.B. (eds.). The birds of North America online. Ithaca: Cornell Laboratory of Ornithology. http://bna.birds. cornell.edu/bna/species/282. (Access on 08 May 2018).

Kennedy M., Holland B.R., Gray R.D. \& Spencer H.G. 2005. Untangling long branches: identifying conflicting phylogenetic signals using spectral analysis, neighbour-net, and consensus networks. Systematic Biology 54: 620-633.

Kitowski I. 2005. Play behaviour and active training of Montagu's Harrier (Circus pygargus) offspring in the post-Hledgling period. Journal of Ethology 23: 3-8.

Mikula P. 2014. Pedestrian density influences flight distances of urban birds. Ardea 102: 53-60.

Mowbray T.B. 2002. Northern Gannet (Morus bassanus). In: Poole A.F. \& Gill F.B. (eds.). The birds of North America. Ithaca: Cornell Laboratory of Ornithology. https://doi.org/10.2173/bna.693 (Access on 08 May 2018).

Orta J. 1992. Family Anhingidae (darters), p. 354-361. In: del Hoyo J., Elliot A. \& Sargatal J. (eds.). Handbook of the birds of the world (ostrich to ducks), v. 1. Barcelona: Lynx Editions.

Prestes T.V., Manica L.T. \& Guaraldo A.C. 2018. Behavioral responses of urban birds to human disturbance in urban parks at Curitiba, Paraná (Brazil). Revista Brasileira de Ornitologia 26: 77-81.

Sazima I. 2008. Playful birds: cormorants and herons play with objects and practice their skills. Biota Neotropica 8: 259-264.

Schodde R., Kirwan G.M. \& Porter R. 2012. Morphological differentiation and speciation among darters (Anhinga). Bulletin of the British Ornithologists' Club 132: 283-294.

Schreiber E.A., Schreiber R.W. \& Schenk G.A. 1996. Red-footed Booby (Sula sula) In: Poole A.F. \& Gill F.B. (eds.). The birds of North America. Ithaca: Cornell Laboratory of Ornithology. https://doi.org/10.2173/bna.241. (Access on 08 May 2018).

Witt D. 2018. Playing catch. https://naturestories.org/playing-catchbd4c4b3a47ad (Access on 15 August 2018).

Associate Editor: Lilian T. Manica. 